\title{
21st Century Projections of Extreme Precipitation Indicators for Cyprus
}

\author{
George Zittis ${ }^{1, *(\mathbb{C})}$, Adriana Bruggeman ${ }^{2}(\mathbb{D})$ and Corrado Camera ${ }^{3}[$ \\ 1 Climate and Atmosphere Research Center, The Cyprus Institute, 2121 Nicosia, Cyprus \\ 2 Energy, Environment and Water Research Center, The Cyprus Institute, 2121 Nicosia, Cyprus; \\ a.bruggeman@cyi.ac.cy \\ 3 Dipartimento di Scienze della Terra 'A. Desio', Università degli Studi di Milano, 20133 Milan, Italy; \\ corrado.camera@unimi.it \\ * Correspondence: g.zittis@cyi.ac.cy
}

Received: 3 March 2020; Accepted: 27 March 2020; Published: 31 March 2020

\begin{abstract}
According to observational and model-based studies, the eastern Mediterranean region is one of the most prominent climate-change hotspots in the world. The combined effect of warming and drying is expected to augment the regional impacts of global warming. In addition to changes in mean climatic conditions, global warming is likely to induce changes in several aspects of extreme rainfall such as duration and magnitude. In this context, we explore the impact of climate change on precipitation with the use of several indicators. We focus on Cyprus, a water-stressed island located in the eastern Mediterranean Basin. Our results are derived from a new high-resolution simulation for the 21st century, which is driven by a "business-as-usual" scenario. In addition to a strong temperature increase (up to $4.1^{\circ} \mathrm{C}$ ), our analysis highlights that, on average for the island, most extreme precipitation indicators decrease, suggesting a transition to much drier conditions. The absolute daily rainfall maxima exhibit strong local variability, indicating the need for high resolution simulations to understand the potential impacts on future flooding.
\end{abstract}

Keywords: climate change; Cyprus; Mediterranean; WRF; temperature; precipitation; dynamical downscaling; extremes

\section{Introduction}

The broader region of the Mediterranean, and particularly the eastern part of the basin, is a well-known climate change hotspot [1,2]. According to most future scenarios and climate projections, a combined drying and warming is expected for the 21st century [3-7]. While the climate projections for temperature are quite robust and their signal is significant, this is not the case for precipitation, which is found to be mainly driven by internal climate variability $[5,7]$. The robustness of climate models is even further reduced when extreme precipitation is considered. Nevertheless, a number of studies have indicated that global warming induced changes in extreme rainfall are also expected, while the signal of these changes could be larger or even opposite to the one for mean changes [8-12].

The very local nature of some precipitation events and the small scales involved in the rainfall formation processes are common sources of climate models' misinterpretations [13]. Therefore, high-resolution regional climate simulations are essential for assessing changes in precipitation, particularly for locations of high topography and complex coastlines that are common in the Mediterranean. A better representation of extreme events by dynamical downscaling through regional climate models is evident in a number of studies [14-17].

Cyprus, a water-stressed Mediterranean island located in the easternmost part of the basin, is characterized by a temperate climate with hot and dry summers, while part of the island is classified 
as hot and arid, according to the Köppen-Geiger system $[13,18]$. The mean annual precipitation is around $470 \mathrm{~mm}$ [19], while most of the water resources originate in the Troodos mountains which cover nearly $30 \%$ of the island [20]. Over the last decades, the observed rainfall trends in this part of the Mediterranean have mostly been negative [21-23].

A high number of regional climate simulations is available for the European continent through the European contributions in the Coordinated Regional Downscaling Experiment (EURO-CORDEX) [24,25]. Nevertheless, Cyprus is located very close to the boundaries of the European simulation domain. This is expected to affect the climate simulations because many of the weather systems that produce rainfall over the eastern Mediterranean are not sufficiently resolved in the EURO-CORDEX domain (e.g., depressions approaching from north Africa or the active Red Sea trough). Therefore, there is a strong need for additional simulations designed for a specific location or application.

There is a very limited number of studies available in the literature that thoroughly discuss climate change projections for Cyprus on a national or local level. Furthermore, these studies have either considered the previous generation of global climate change scenarios [26-28] or focused on other variables than precipitation [29].

In this respect and considering that the observed climate trends over Cyprus and the broader region will likely continue or exacerbate during the 21st century [21-23,26-28], we present a new high-resolution $(12-\mathrm{km})$ regional climate simulation that is optimized for the representation of precipitation extremes in the eastern Mediterranean environment. Thus, the objectives of this study are (a) to explore the skill of a new high-resolution regional climate simulation in representing key hydrometeorological variables for Cyprus and (b) to assess the local effect of climate change with a focus on mean temperature and several aspects of precipitation. The new regional simulation is also compared with an ensemble of 26 EURO-CORDEX simulations of the same resolution.

\section{Methods and Data}

\subsection{Simulation Design}

For the present study we performed an "in-house" regional climate simulation covering the eastern Mediterranean during the period from 1981 to 2100. We used the Weather Research and Forecasting (WRF) model [30] as a dynamical downscaling tool [31]. The 12-km simulation domain was centered over Cyprus and is depicted in the top left panel of Figure 1. The model was optimized for simulating precipitation in the study region and the configuration was similar to [13]. In terms of parameterization schemes for sub-grid scale processes, our model setup included the Eta (Ferrier) microphysics (NOAA 2001), the rapid radiation transfer model short- and long-wave radiation [32], the Betts-Miller-Janjic cumulus parameterization [33], the Mellor-Yamada-Janjic planetary boundary layer scheme [33], in addition to the Noah Land Surface Model [34]. As initial and lateral boundary conditions, we employed 6-hourly bias-adjusted output from the global CESM1 Earth System Model [35,36]. This type of driving data, which have a global coverage and a horizontal resolution of $1.25^{\circ}$, is fully compatible with WRF. Moreover, in order to prevent a decoupling between the global and regional simulations [37], we applied a "weak" analysis nudging (nudging coefficients for U and V wind components: guv = $10^{-5}$, for temperature: $\mathrm{gt}=10^{-5}$, and for specific humidity: $\mathrm{gq}=10^{-6}$ ). The greenhouse gas forcing followed the RCP8.5 "business-as-usual” future pathway [38]. 


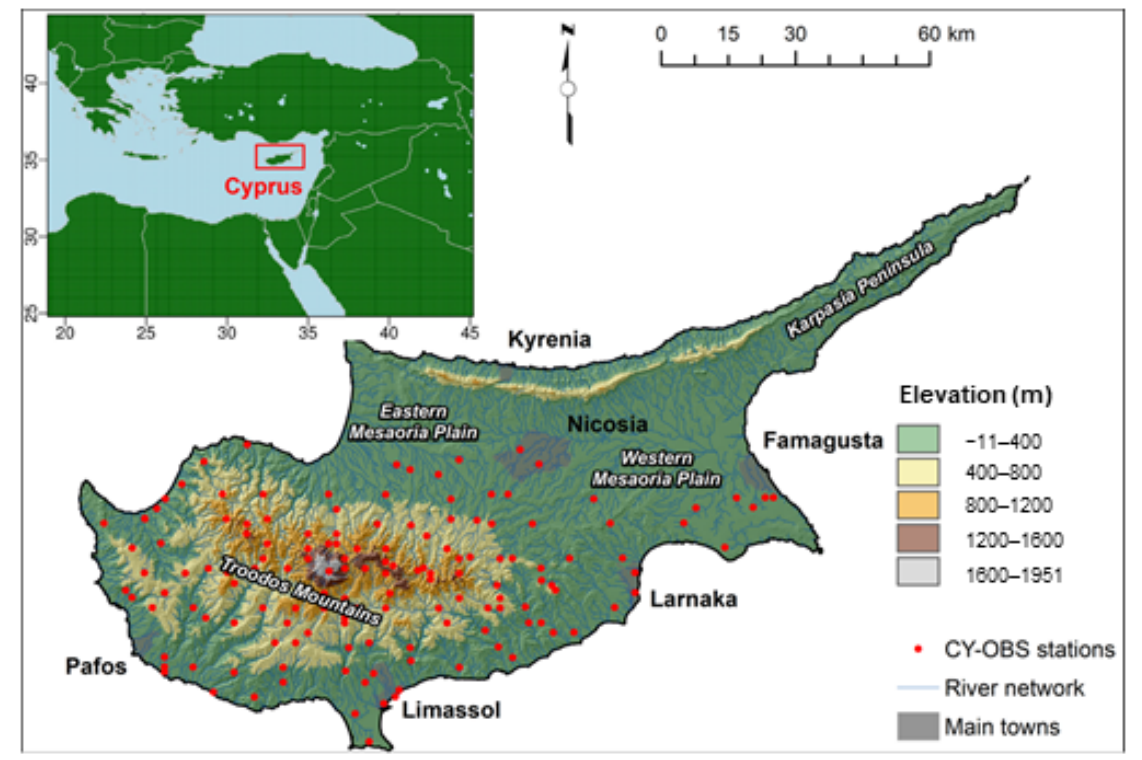

Figure 1. Extend of the simulation domain (top left), main topographic characteristics of the island of Cyprus and location of weather stations.

\subsection{Observational Data}

For the evaluation of the model output we used a daily $1 \times 1 \mathrm{~km}$ gridded dataset for precipitation and temperature [19,39], hereafter called CY-OBS. This high-resolution dataset covers the period from 1980 to 2010 and it was derived from the statistical interpolation of a very dense network of weather stations. Unfortunately, this dataset covers only the area of the island that is currently under the jurisdiction of the Republic of Cyprus.

\subsection{CORDEX Data}

For comparison purposes, we have also explored data from the European initiative of the Coordinated Regional Downscaling Experiment (EURO-CORDEX) [24]. Annual time-series of temperature and precipitation were extracted for the region of Cyprus. In total, 26 EURO-CORDEX simulations of $12-\mathrm{km}$ horizontal resolution were considered (Table 1). Their range and ensemble median were compared with our simulation. These EURO-CORDEX simulations were driven by the RCP8.5 pathway.

\subsection{Sub-Periods of Analysis}

For our analysis we considered the 30-year period from 1981 to 2010 as our historical period. This was used for a comparison with the gridded observations and as a reference period for calculating future changes. For the future, we selected one 30-year period representative for the middle of the 21st century (MID, 2031 to 2060) and one period representative for the climate conditions towards the end of the 21st century (END, 2071 to 2100). 
Table 1. List of EURO-CORDEX simulations used for comparison (see ref. [40] for more details and model abbreviations).

\begin{tabular}{|c|c|c|}
\hline & Driving Global Model & Regional Climate Model \\
\hline 1. & CNRM-CERFACS-CNRM-CM5 (r1i1p1) & CLMcom-CCLM4-8-17_v1 \\
\hline 2. & CNRM-CERFACS-CNRM-CM5 (r1i1p1) & CNRM-ALADIN63_v2 \\
\hline 3. & CNRM-CERFACS-CNRM-CM5 (r1i1p1) & DMI-HIRHAM5_v2 \\
\hline 4. & CNRM-CERFACS-CNRM-CM5 (r1i1p1) & KNMI-RACMO22E_v2 \\
\hline 5. & CNRM-CERFACS-CNRM-CM5 (r1i1p1) & RMIB-UGent-ALARO-0_v1 \\
\hline 6. & CNRM-CERFACS-CNRM-CM5 (r1i1p1) & SMHI-RCA4_v1 \\
\hline 7. & ICHEC-EC-EARTH (r12i1p1) & CLMcom-CCLM4-8-17_v1 \\
\hline 8. & ICHEC-EC-EARTH (r12i1p1) & DMI-HIRHAM5_v1 \\
\hline 9. & ICHEC-EC-EARTH (r12i1p1) & KNMI-RACMO22E_v1 \\
\hline 10. & ICHEC-EC-EARTH (r12i1p1) & SMHI-RCA4_v1 \\
\hline 11. & ICHEC-EC-EARTH (r3i1p1) & KNMI-RACMO22E_v1 \\
\hline 12. & ICHEC-EC-EARTH (r3i1p1) & SMHI-RCA4_v1 \\
\hline 13. & IPSL-IPSL-CM5A-MR (r1i1p1) & SMHI-RCA4_v1 \\
\hline 14. & MOHC-HadGEM2-ES (r1i1p1) & CLMcom-CCLM4-8-17_v1 \\
\hline 15. & MOHC-HadGEM2-ES (r1i1p1) & MOHC_HadREM_v1 \\
\hline 16. & MOHC-HadGEM2-ES (r1i1p1) & DMI-HIRHAM5_v1 \\
\hline 17. & MOHC-HadGEM2-ES (r1i1p1) & KNMI-RACMO22E_v2 \\
\hline 18. & MOHC-HadGEM2-ES (r1i1p1) & SMHI-RCA4_v1 \\
\hline 19. & MOHC-HadGEM2-ES (r1i1p1) & ICTP_RegCM4_v1 \\
\hline 20. & MPI-M-MPI-ESM-LR (r1i1p1) & CLMcom-CCLM4-8-17_v1 \\
\hline 21. & MPI-M-MPI-ESM-LR (r1i1p1) & MPI-CSC-REMO2009_v1 \\
\hline 22. & MPI-M-MPI-ESM-LR (r1i1p1) & SMHI-RCA4_v1 \\
\hline 23. & NCC-NorESM1-M (r1i1p1) & DMI-HIRHĀM5_v2 \\
\hline 24. & NCC-NorESM1-M (r1i1p1) & GERICS-REMO2015_v1 \\
\hline 25. & NCC-NorESM1-M (r1i1p1) & KNMI-RACMO22E_v1 \\
\hline 26. & NCC-NorESM1-M (r1i1p1) & SMHI-RCA4_v1 \\
\hline
\end{tabular}

\subsection{Indices of Precipitation}

In addition to assessing annual temperature means and precipitation totals, we also explored five indices of precipitation characteristics [41,42]. These are part of the list suggested by the World Meteorological Organization's Expert Team on Climate Change Detection and Indices (ETCCDI) and are defined as follows:

- Consecutive dry days (CDD) and the greatest number of consecutive days with precipitation lower than $1 \mathrm{~mm}$, within a year;

- Consecutive wet days (CWD) are the greatest number of consecutive days with precipitation higher or equal to $1 \mathrm{~mm}$, within a year;

- Annual count of rainy days (RR1) is the annual count of days with observed rainfall greater than $1 \mathrm{~mm}$;

- Annual count of days with precipitation larger than $20 \mathrm{~mm}$ (R20);

- Highest five-day precipitation amount for each year (RX5D).

In addition, for the total length of each 30-year sub-period of analysis, we calculated the absolute maximum daily precipitation (RXa) for both the observed records and the modeled rainfall. For the quantitative evaluation of these precipitation indices, we regridded the $1 \mathrm{~km}$ observational dataset to the $12 \mathrm{~km}$ model grid.

\section{Results}

\subsection{Mean Climatic Conditions}

The observed and modeled annual precipitation climatology for the 1981 to 2010 reference period is presented in Table 2 and in the top panels of Figure 2. According to the CY-OBS gridded observations, 
the maximum amounts of rainfall was found in the peaks of the Troodos mountain. Locally, the 30-year annual rainfall average exceeded $1000 \mathrm{~mm}$. In contrast, near the coastal areas of the southeast and in the inland areas of the Measoria Plain, the annual rainfall could be less than $300 \mathrm{~mm}$. We found the WRF simulation adequately reproduced the spatial patterns of rainfall, however, it tended to underestimate its magnitude, particularly over the mountainous grid cells. This is somehow expected, since in this $12 \mathrm{~km}$ simulation, the model elevation of the highest grid point did not exceed $850 \mathrm{~m}$, while in reality the peak of the Troodos mountains is much higher in altitude (1952 m). As a result, the orographic effect on precipitation formation was underestimated.

Table 2. Observed (CY-OBS) and modeled Weather Research and Forecasting (WRF) values of mean annual temperature $(\mathrm{T})$, precipitation $(\mathrm{P})$, consecutive dry days (CDD), consecutive wet days (CWD), number of rainy days (RR1), maximum 5-day precipitation (R5D), number of days with precipitation greater than $20 \mathrm{~mm}$ (R20), and absolute maximum daily rainfall (RXa) for the historical reference period (1981 to 2010). The values represent means and ranges across the $5112 \mathrm{~km}$ grid points, with the CY-OBS grid points interpolated to the model's grid.

\begin{tabular}{cccccccccc}
\hline & & $\mathbf{T}\left({ }^{\circ} \mathbf{C}\right)$ & $\mathbf{P}(\mathbf{m m})$ & $\begin{array}{c}\text { CDD } \\
\text { (days) }\end{array}$ & $\begin{array}{c}\text { CWD } \\
\text { (days) }\end{array}$ & $\begin{array}{c}\text { RR1 } \\
(\text { days })\end{array}$ & $\begin{array}{c}\text { R5D } \\
(\mathbf{m m})\end{array}$ & $\begin{array}{c}\text { R20 } \\
(\text { days })\end{array}$ & $\begin{array}{c}\text { RXa } \\
(\mathbf{m m})\end{array}$ \\
\hline \multirow{2}{*}{ CY-OBS } & Min & 12.2 & 266 & 57 & 4.5 & 39 & 52.3 & 1.8 & 69 \\
& $\begin{array}{c}\text { Mean } \\
\text { Max }\end{array}$ & 18.1 & 476 & 104.5 & 6 & 53.3 & 90.9 & 5.6 & 106 \\
& 19.6 & 928 & 146.2 & 8.1 & 74.9 & 166.8 & 14.1 & 202 \\
\multirow{2}{*}{ WRF } & Min & 15.2 & 210 & 47.1 & 4.6 & 35.8 & 44.5 & 1.1 & 43 \\
& Mean & 18.9 & 379 & 112.2 & 5.9 & 51.8 & 66.7 & 3.5 & 85 \\
& Max & 21.1 & 761 & 162.1 & 7.7 & 80.7 & 126.2 & 9.6 & 169 \\
\hline
\end{tabular}
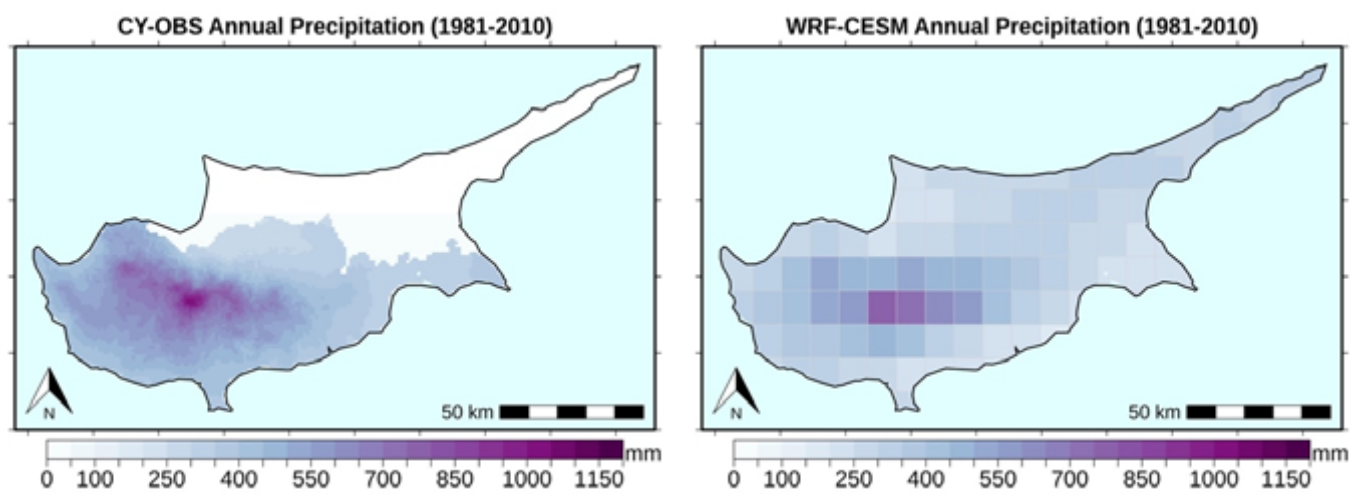

WRF-CESM-RCP8.5 Annual Precipitation Change
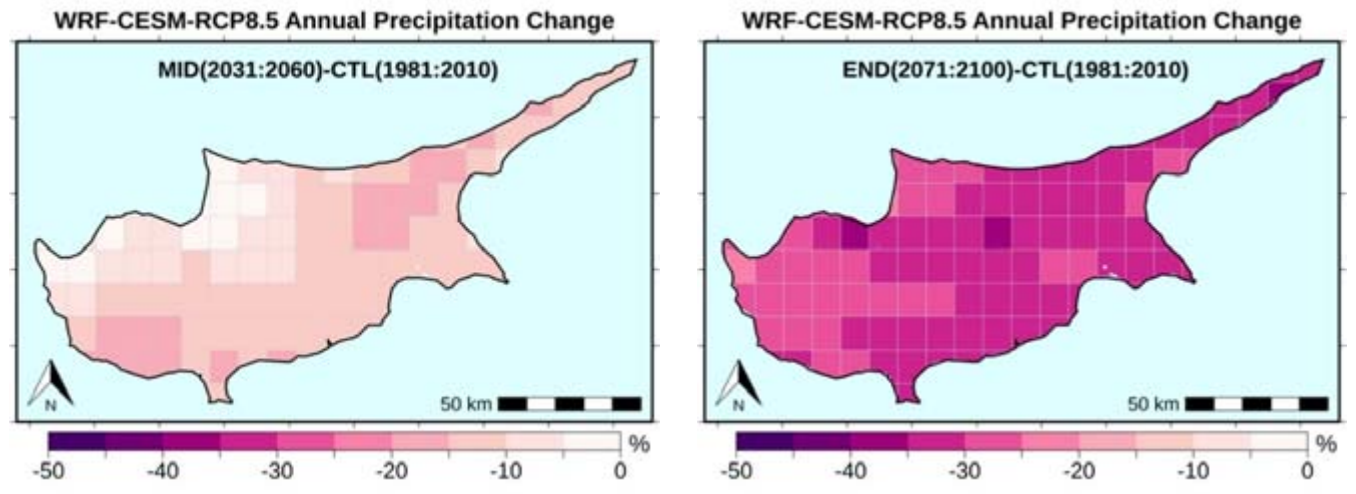

Figure 2. Observed (top left) and simulated (top right) annual precipitation total for the period 1981 to 2010 and projected changes for the middle (bottom left) and end of the 21st century (bottom right).

For the future, the model simulation suggests a drier climatic regime for Cyprus (Figure 2 bottom panels, Figure 3 and Table 3). Decreases in the range of $10 \%$ to $15 \%$, with respect to the reference period, 
are projected for the middle of the 21st century. Under this "business-as-usual" pathway, changes of precipitation are found much stronger (25\% to 35\%) towards the end of the century. This projected decrease in rainfall, which is also evident in the time series of Figure 3, is expected to have a strong impact on the water resources of the island, and thus is expected to cause serious implications for several socioeconomic sectors. The thin line segments of Figure 3 represent the range and ensemble median of the 26 EURO-CORDEX simulations. Interestingly, our regional simulation is found to be within the EURO-CORDEX range for all sub-periods. However, it is found to be in the dry end of this ensemble set.

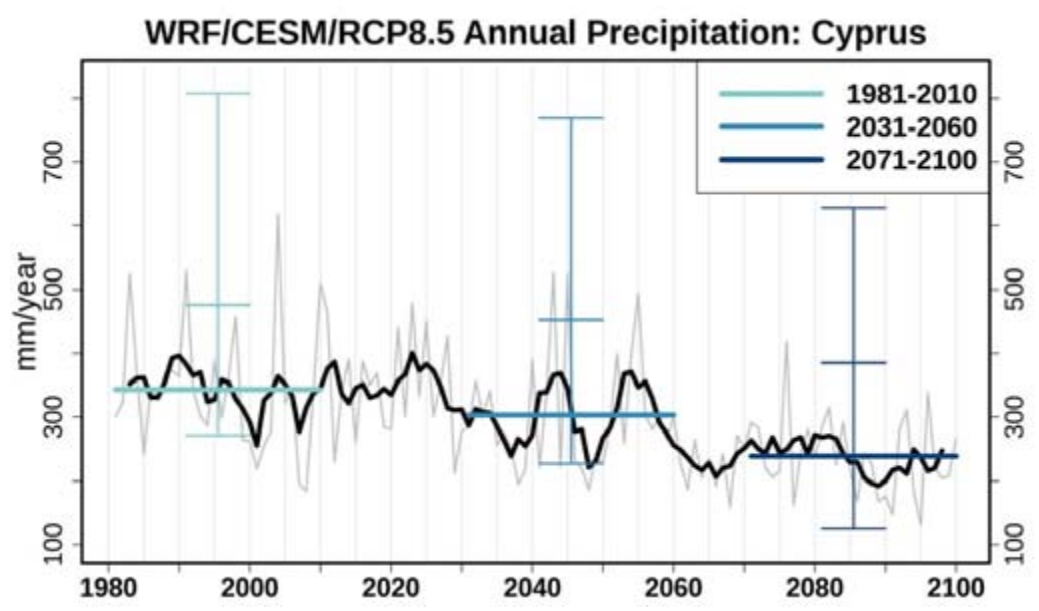

Figure 3. Simulated annual precipitation (grey), 5-year moving average (black), 30-year averages (colored), and median and range of 26 EURO-CORDEX simulations (error bars), over Cyprus.

Table 3. Projected changes between the control reference period (CTL: 1981-2010) and each future period (MID: 2031-2060 and END: 2071-2100) for mean annual temperature (T), precipitation (P), consecutive dry days (CDD), consecutive wet days (CWD), number of rainy days (RR1), maximum 5-day precipitation (R5D), number of days with precipitation greater than $20 \mathrm{~mm}$ (R20) and absolute maximum daily rainfall ( $\mathrm{RXa})$.

\begin{tabular}{cccccccccc}
\hline & & T ( $\left.{ }^{\circ} \mathbf{C}\right)$ & P (\%) & $\begin{array}{c}\text { CDD } \\
\text { (days) }\end{array}$ & $\begin{array}{c}\text { CWD } \\
\text { (days) }\end{array}$ & $\begin{array}{c}\text { RR1 } \\
\text { (days) }\end{array}$ & $\begin{array}{c}\text { R5D } \\
(\mathbf{m m})\end{array}$ & $\begin{array}{c}\text { R20 } \\
(\text { days })\end{array}$ & $\begin{array}{c}\text { RXa } \\
(\%)\end{array}$ \\
\hline \multirow{2}{*}{ WRF } & Min & 1.4 & -16.8 & -8.4 & -1.8 & -9.8 & -17.1 & -1.6 & -68.5 \\
MID-CTL & Mean & 1.8 & -11.5 & 4 & -0.8 & -6.8 & -1.5 & -0.1 & -20.4 \\
& Max & 1.9 & -1.5 & 16.7 & 0.3 & -4.1 & 11.4 & 0.6 & 81.8 \\
\hline \multirow{2}{*}{ WRF } & Min & 3 & -35.9 & 3.5 & -2.5 & -21.7 & -32.1 & -2.5 & -71.7 \\
END-CTL & Mean & 3.7 & -30.7 & 19.5 & -1.3 & -14.9 & -11.3 & -0.7 & -12.9 \\
& Max & 4.1 & -24.3 & 41.2 & -0.6 & -11 & 5.5 & 0.3 & 88.1 \\
\hline
\end{tabular}

The observed average annual temperature climatology according to CY-OBS is presented in the top left panel of Figure 4. The spatial pattern of temperature follows the topography of Cyprus, with higher temperatures (up to $20^{\circ} \mathrm{C}$ ) observed in the low-elevation coastal and inland parts of the island and lower annual temperatures $\left(12{ }^{\circ} \mathrm{C}\right)$ in the high-elevation regions of Troodos. Mean temperature averaged over the historical period of our simulation is presented in the top right panel of Figure 4 and is summarized in Table 2. The spatial gradient is very similar to the observations; nevertheless, the model seems to overestimate temperature. This overestimation, which is $0.8{ }^{\circ} \mathrm{C}$ on average across the island, can be partly attributed to the misrepresentation of orography. As expected, it is found to be of greater significance in the peaks of the Troodos mountains.

For the future temperature conditions and by the middle of the 21st century, the WRF simulations project a warming in the range $1.5-2.0^{\circ} \mathrm{C}$, with respect to the historical reference period (Figure 4 bottom left panel). Under the investigated scenario, the warming for Cyprus is projected to exacerbate 
during the last decades of the century. In more detail, it is expected to exceed $4.0^{\circ} \mathrm{C}$ for the central parts of the island (Figures 4 and 5). The range of projected annual temperature changes is also summarized in Table 3. Figure 5 reveals that the suggested temperature increase is found to be within the range of the EURO-CORDEX simulations, which is indicated by the error bars.
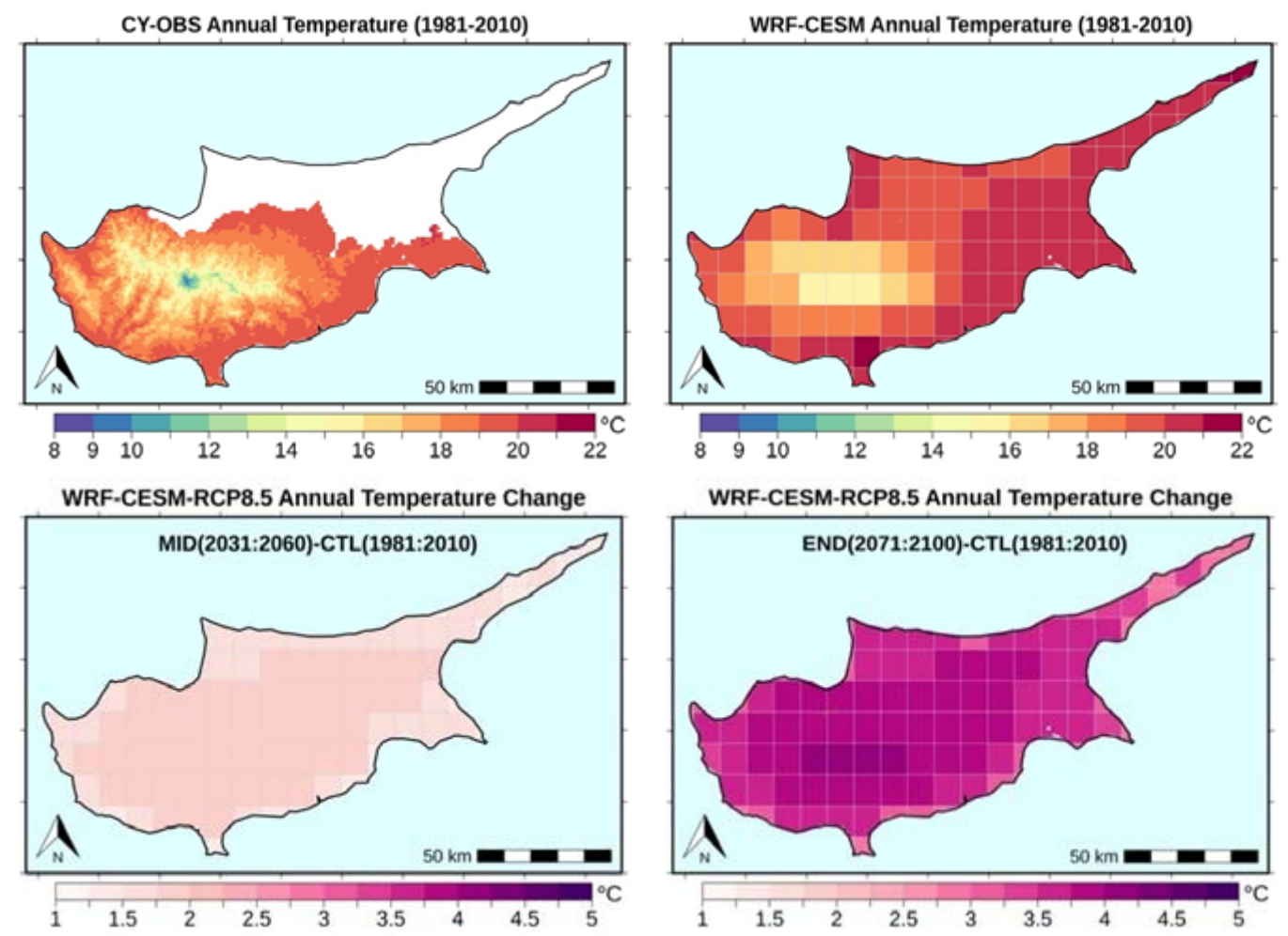

Figure 4. Observed (top left) and simulated (top right) average annual mean temperature for the period 1981 to 2010 and projected changes for the middle (bottom left) and end of the 21st century (bottom right).

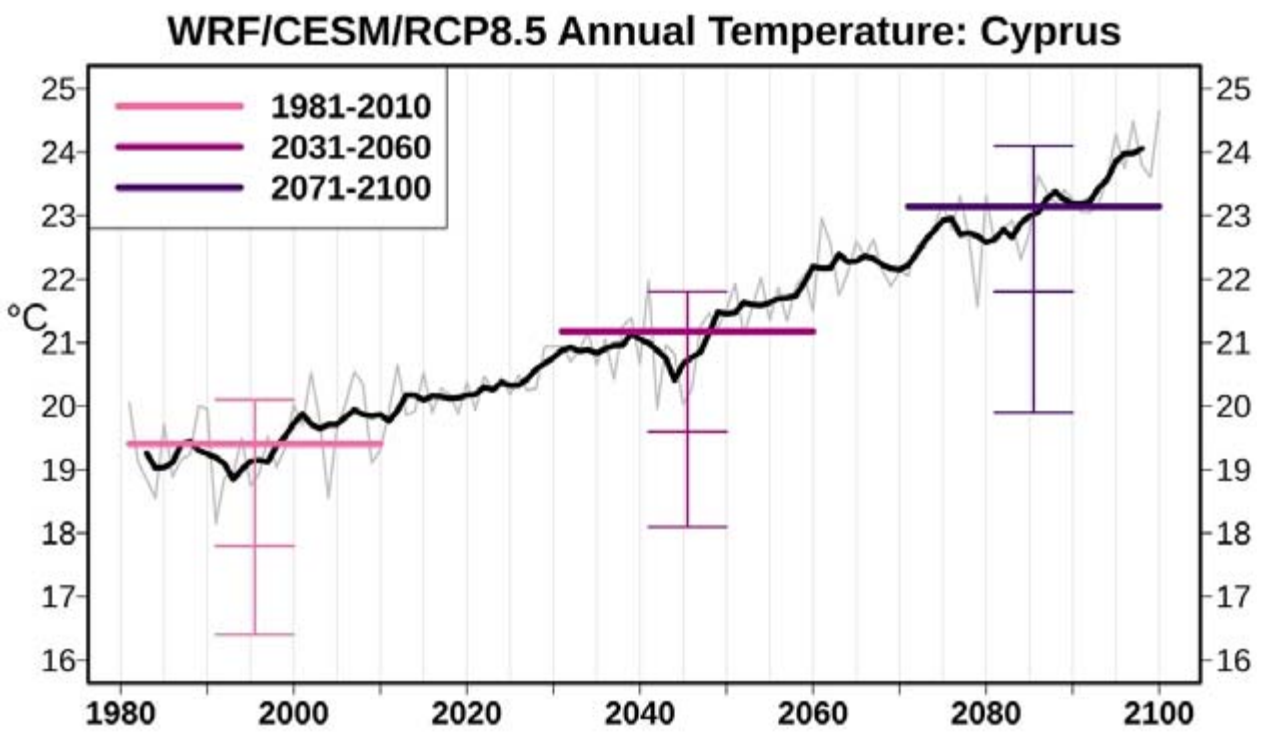

Figure 5. Simulated mean temperature (grey), 5-year moving average (black), 30-year averages (colored), and median and range of 26 EURO-CORDEX simulations (error bars), over Cyprus. 


\subsection{Precipitation Characteristics}

\subsubsection{Consecutive Dry Days (CDD)}

The observed average number of maximum consecutive dry days (CDD) per year ranges from 50 to 60 days in the mountains to 130 to 150 days in most of the coastal areas (Table 2 and Figure 6 top left). For the historical reference period, the model is within the observed range for most of the island (Table 2 and Figure 6 top right). The future projection for the period 2031 to 2060 indicates mild increases in the range of five to ten additional days in the longest dry spells for most of the island (Figure 6 bottom panels). For some dispersed grid cells the climate change signal has a different sign and small decreases (up to eight fewer days) are simulated. Contrarily, strong increases in the length of dry spells are expected by the end of the century (Table 3). Particularly for the south and east parts of the island, the longest dry spells of the year are likely to be extended by four to six additional weeks. This is expected to have a strong impact on water supply and agricultural activities particularly for the extended dry period of the year. Additionally, in combination with the significant temperature increases presented in the previous section it will also strongly affect sensitive ecosystems such as forests and wetlands throughout the island.
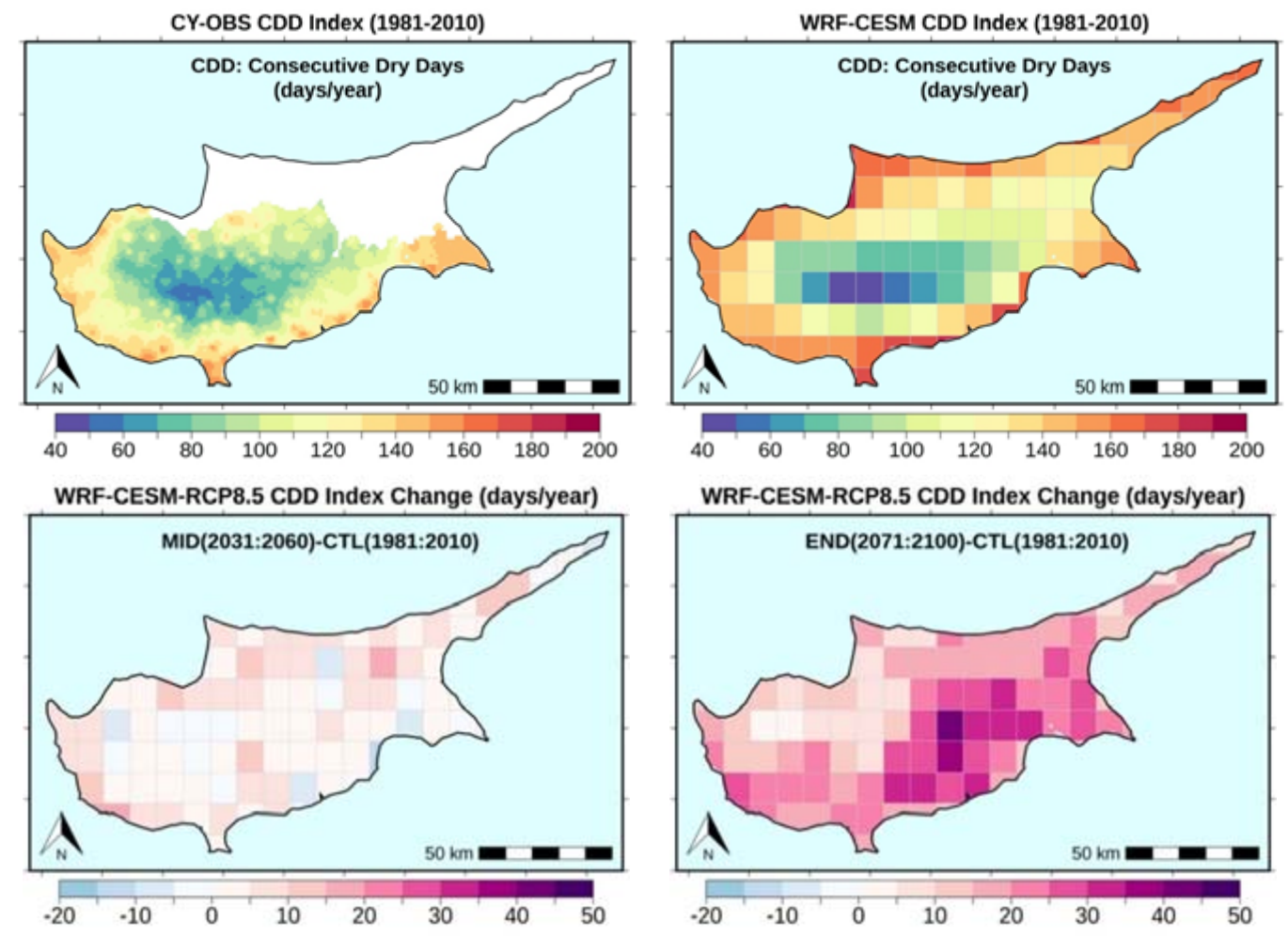

Figure 6. Observed (top left) and simulated (top right) maximum number of consecutive dry days per year (CDD) for the period 1981 to 2010 and projected changes for the middle (bottom left) and end of the 21st century (bottom right).

\subsubsection{Consecutive Wet Days (CWD)}

This index is of great importance when it comes to replenishing the underground and surface water resources of the semi-arid parts of the island. Over the broader area of Cyprus, most of the precipitation is related to wintertime baroclinic depressions that approach the island from the west and are active over the region for a few days $[43,44]$. Therefore, the observed number of consecutive wet days is higher in the western part of the island (six to eight days) and peaks over the western summits of Troodos (Figure 7 top left). For this indicator, the WRF simulation effectively captures the Troodos peaks and the southeastern part of Cyprus. However, it is found to underestimate the length of wet 
spells by one to three days in the western part of the island (Figure 7 top right). For the end of the 21st century (2071 to 2100) the WRF simulation suggests a decrease of the maximum wet spell length by one to three days (Table 2), with the most significant decrease in the central part of the island (Figure 7 bottom panels). For the 2031 to 2060 period, the signal of change is also mostly negative, however the model suggests milder decreases (up to 1.8 days).
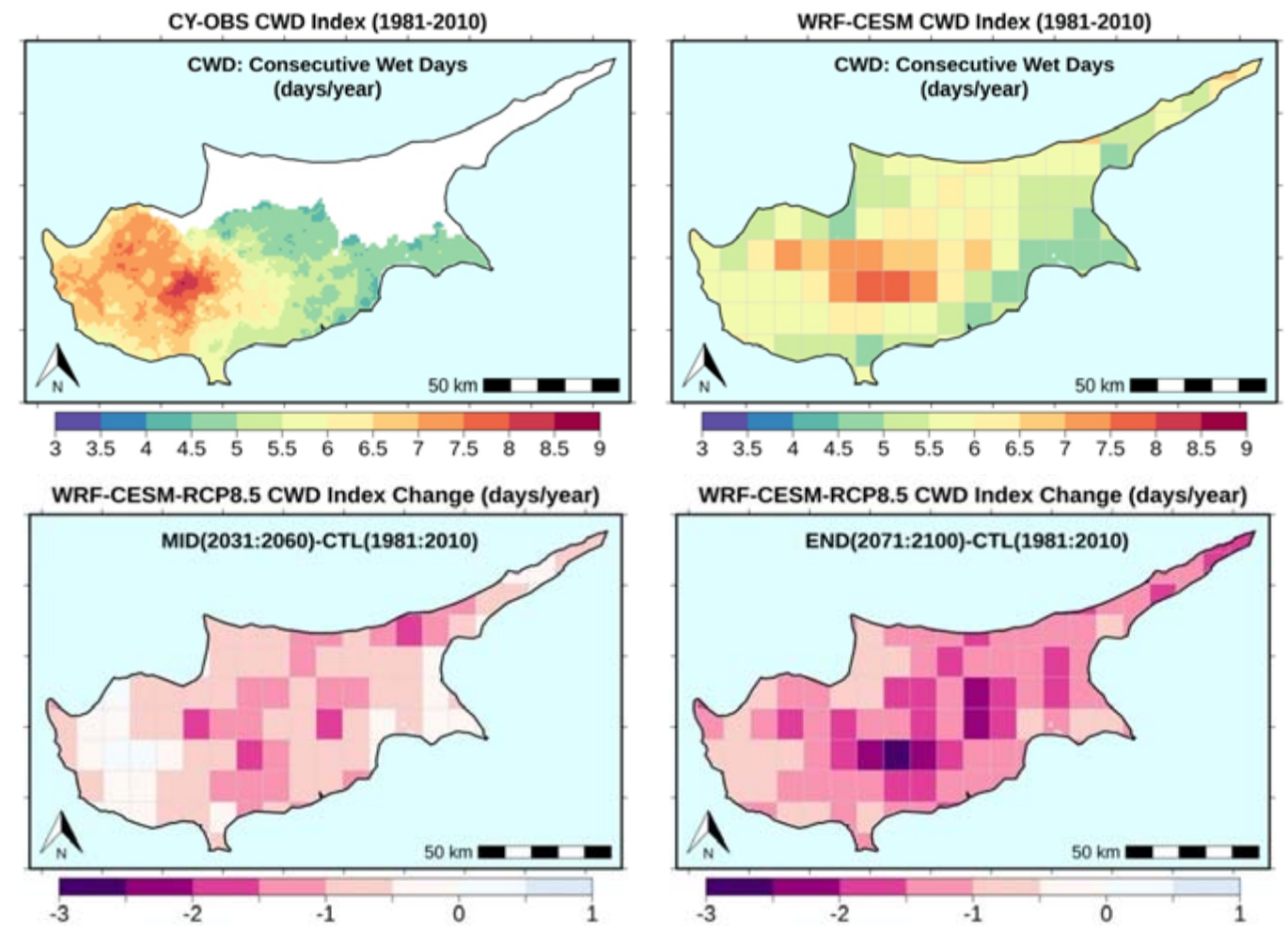

Figure 7. Observed (top left) and simulated (top right) maximum number of consecutive wet days per year (CWD) for the period 1981 to 2010 and projected changes for the middle (bottom left) and end of the 21st century (bottom right).

\subsubsection{Number of Rainy Days (RR1)}

The number of rainy days per year, averaged for the historical reference period, ranges from 75 days in Troodos to less than 40 days in the drier east coast (Table 2 and Figure 8). The model captures relatively well this west-to-east gradient and the observed range of rainy days per year. These numbers are also projected to decrease in a warmer future (Figure 8 bottom panels). A reduction of up to ten rainy days per year is expected by the middle of the 21st century. According to the tested scenario, the decrease in the number of rainy days should continue towards the end of the century. By 2100, Cyprus should likely experience 15 to 20 less days when precipitation occurs. The strongest decreases are estimated for the central part of the island, which is the area that contributes most to the water resources.

\subsubsection{Maximum Five-Day Precipitation (RX5D)}

This indicator is relevant for extreme rainfall events that could trigger flooding. The observed gradient is quite strong, since the maximum five-day precipitation sum, averaged over the 30-year period, ranges from about $170 \mathrm{~mm}$ in Troodos peaks to $50 \mathrm{~mm}$ in the lowland parts of the Mesaoria Plain (Figure 9). The model simulation tends to underestimate these numbers by 20 to $40 \mathrm{~mm}$ throughout the island (Table 2). The climate change signal for the middle of the 21st century is diverse (Figure 9 bottom panels and Table 3). On the one hand, for some locations, mainly in the west part of the country, the model suggests a mild increase of this indicator (up to $10 \mathrm{~mm}$ ). On the other hand, 
for other locations, mainly in the central and north east, the model suggests a mild decrease of the same magnitude. The changes for the 2071 to 2100 period are projected to be much more pronounced. The reduction of RX5D is likely to exceed $40 \mathrm{~mm}$ over the central parts of the island. For a small region in the west tip of the island, the maximum five-day precipitation is projected to increase by $10 \mathrm{~mm}$ even towards the end of the 21st century.
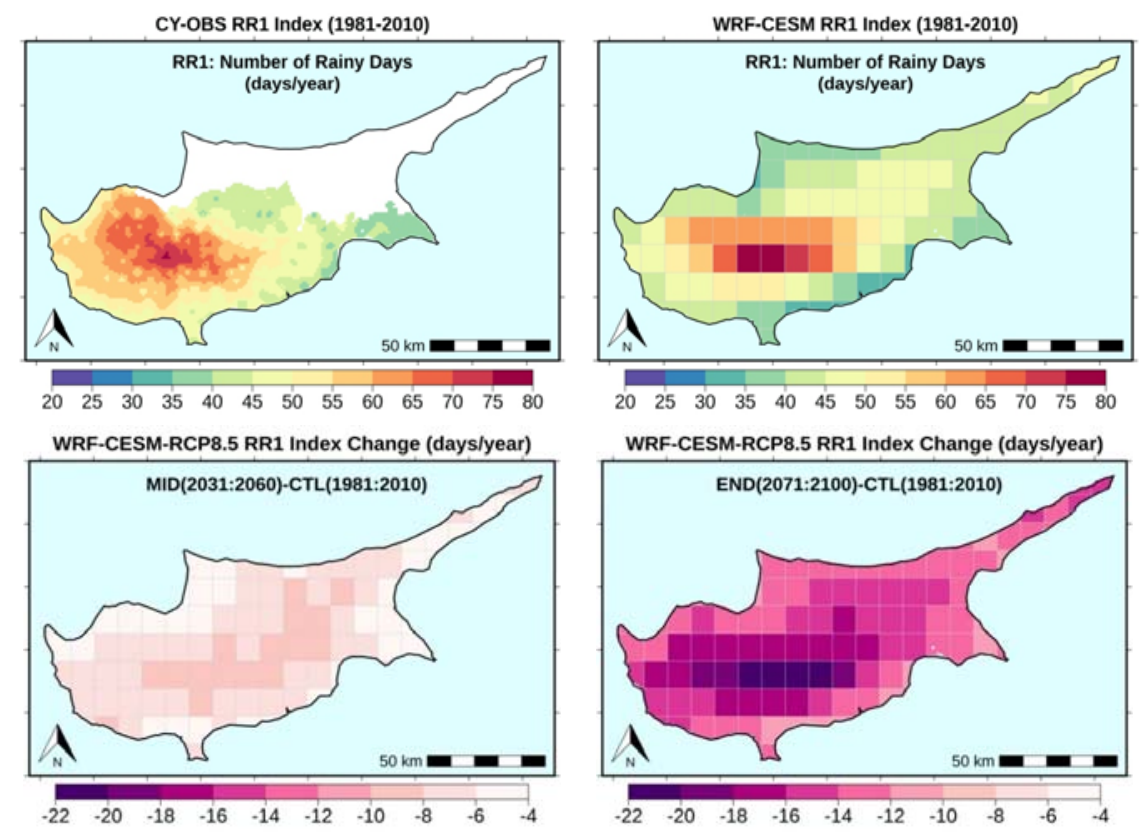

Figure 8. Observed (top left) and simulated (top right) number of rainy days per year (RR1) for the period 1981 to 2010 and projected changes for the middle (bottom left) and end of the 21st century (bottom right).
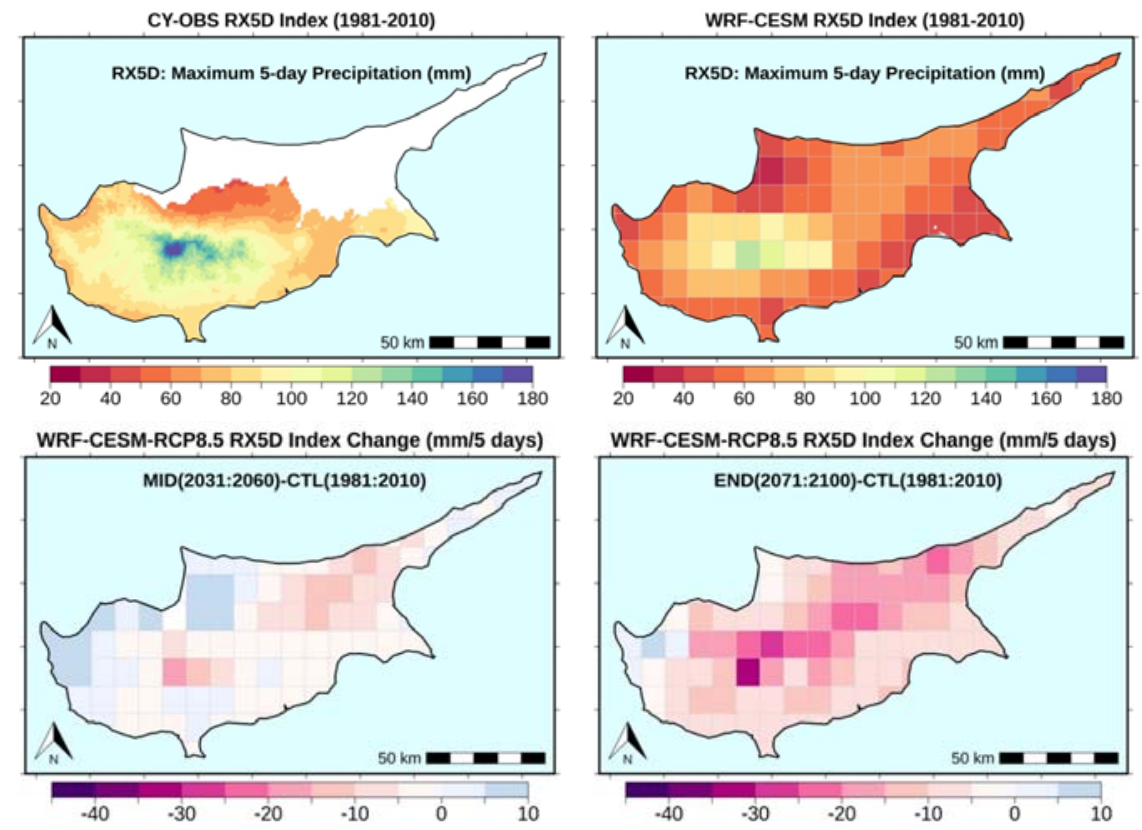

Figure 9. Observed (top left) and simulated (top right) maximum 5-day precipitation per year (RX5D) for the period 1981 to 2010 and projected changes for the middle (bottom left) and end of the 21st century (bottom right). 


\subsubsection{Annual Count of Days with Heavy Precipitation (R20)}

The heavy precipitation days are considered to be days with precipitation greater than $20 \mathrm{~mm}$. According to CY-OBS, this number ranges from two to 14 days per year with an average value of 5.6 days per year (Table 2 and Figure 10). The WRF model in this $12 \mathrm{~km}$ setup, tends to underestimate these numbers up to five days. For the middle of the current century, the model simulation indicates a general decrease in the number of heavy precipitation days, which is mostly evident in the central part of the island (Figure 10 bottom left). This decrease is in the range of one to two days per year. This decreasing signal becomes stronger and is extended throughout the island as we move towards the end of the 21st century (Figure 10 bottom right).

\subsubsection{Absolute Maxima of Daily Precipitation (RXa)}

The top panels of Figure 11 depict the observed and modeled absolute 30-year maximum of daily precipitation that were, respectively, recorded and simulated within the 1981 to 2010 historical reference period. The observed values range from 70 to $200 \mathrm{~mm}$ with an average value across the island equal to $100 \mathrm{~mm}$ (Table 2). Maximum amounts are mainly found in the Troodos mountains, nevertheless other locations (e.g., northwest and southeast coasts) have also experienced very high amounts of daily rainfall in the past. The model results fall within this range, however, the model tends to underestimate the observed values by $20 \mathrm{~mm}$, on average. The observations and the model both clearly show the high variability of the occurrence of extreme precipitation events. This can also be seen in the future 30-year periods (Figure 11 bottom panels). Interestingly, and despite the strong drying trends for the 21 st century, our simulation indicates that, for about $25 \%$ of the grid cells, the absolute 30 -year daily precipitation maximum is expected to increase (Figure 11 bottom panels). Thus, whereas, relative to the period from 1981 to 2010, the average of the 30-year maximum precipitation over all grid cells is projected to decrease by $20 \%$ from 2031 to 2060 and by 13\% from 2071 to 2100 , higher future extremes can be expected at single grid cells. These increases can locally reach $80 \%$ of the absolute maximum that was simulated for the control reference period (Table 3).
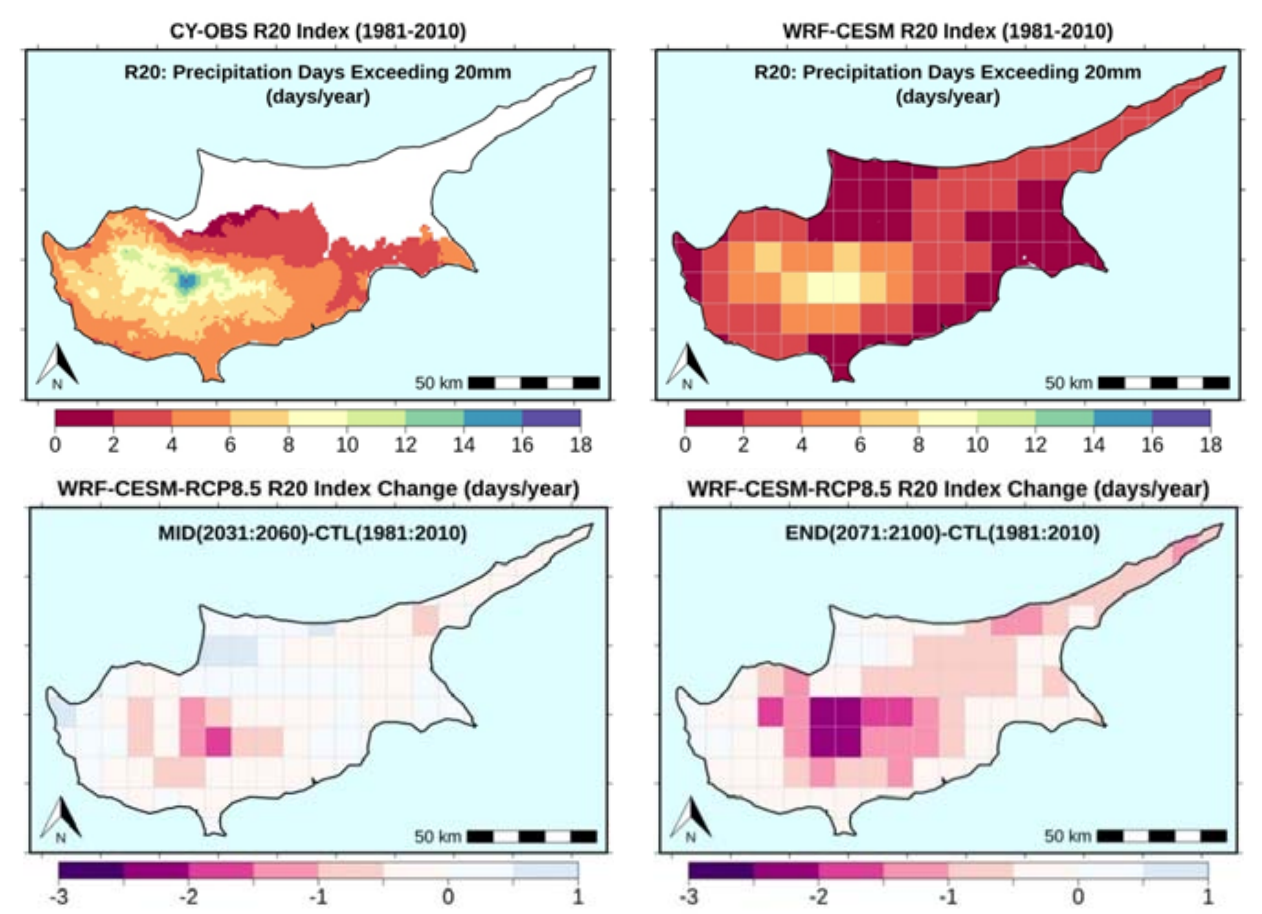

Figure 10. Observed (top left) and simulated (top right) number of heavy precipitation days per year (R20) for the period 1981 to 2010 and projected changes for the middle (bottom left) and end of the 21st century (bottom right). 
CY-OBS Absolute Maximum Daily Precipitation (1981-2010)

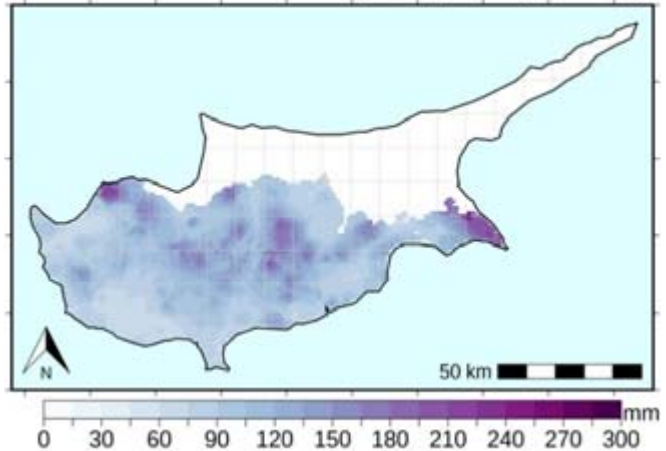

WRF-CESM Change of Absolute Maximum Daily Precipitation

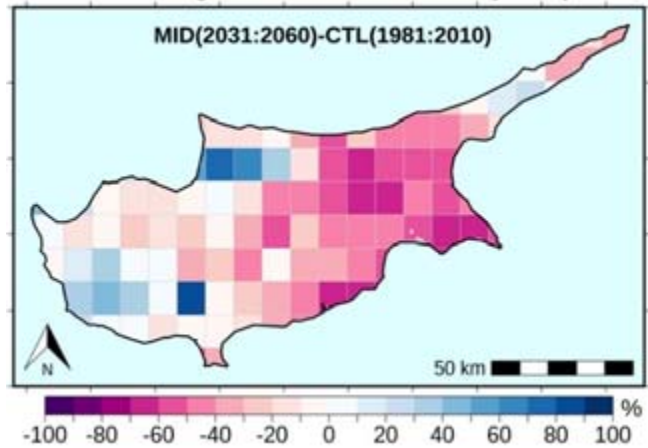

WRF-CESM Absolute Maximum Daily Precipitation (1981-2010)

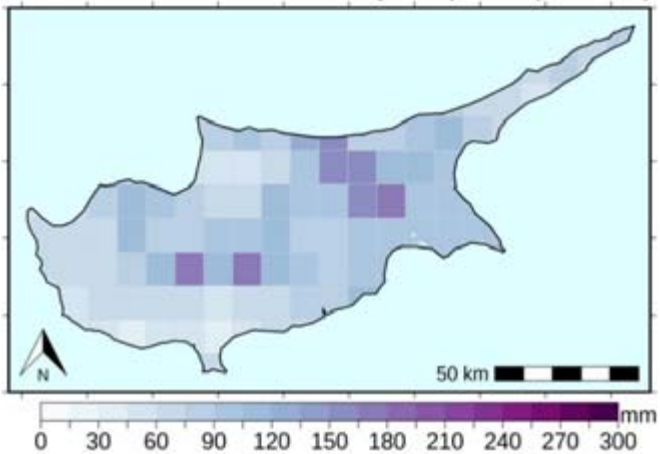

WRF-CESM Change of Absolute Maximum Daily Precipitation

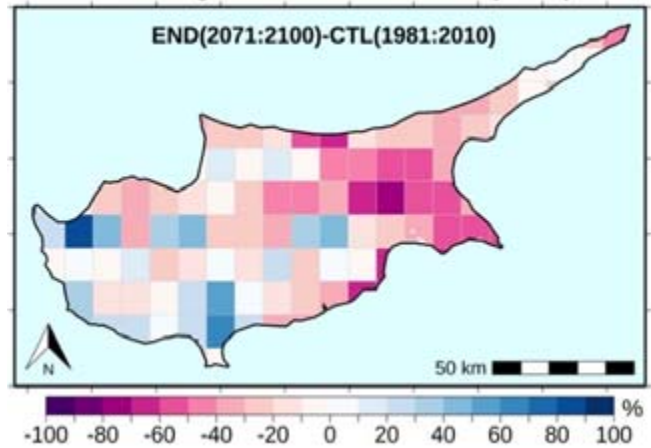

Figure 11. Observed (top left) and simulated (top right) absolute maximum daily precipitation per sub-period (RXa) for the period 1981 to 2010 and projected changes (\%) for the middle (bottom left) and end of the 21st century (bottom right).

\section{Discussion and Conclusions}

In this study, we present a new high-resolution $(12 \mathrm{~km})$ simulation optimized for the simulation of rainfall in the eastern Mediterranean. We compare this model output with a $1 \mathrm{~km}$ gridded observational daily dataset for Cyprus. In general terms, our model is found to reasonably reproduce the spatial characteristics of several precipitation indicators. Nonetheless, it tends to underestimate the quantities of annual precipitation totals by $20 \%$ on average. This underestimation is also important when it comes to indicators of extreme rainfall (e.g., RX5D and R20). This underestimation is most likely caused by the representation of orography in this $12 \mathrm{~km}$ simulation, with the altitudes of the mountain grid cells substantially lower than the observed elevations.

Future changes, under a "business-as-usual" pathway, were also assessed. Our simulation suggests that the trends towards a drier and warmer climatic regime should continue throughout the 21st century. This becomes more evident towards the end of the century. Projected changes in several precipitation characteristics also suggest a transition to harsher climatic conditions. Interestingly, and in disagreement with global trends $[8,10,45]$, the absolute 30 -year daily precipitation extremes are projected to decrease in four-fifths of the Cyprus grid cells by mid-century and in three-quarters of the area by the end of the 21st century. This could have strong effects on future flood events and highlights the need for a more thorough analysis of changes in extreme precipitation events.

The presented results are in general agreement with other studies for the eastern Mediterranean [4-7], nevertheless, here we provide a higher level of detail for the region. Moreover, the range of changes for Cyprus, presented in the current study, is within the range of previous studies for the island, which are, however, driven by an outdated set of global climate models and scenarios.

Our analysis also indicates that, regardless of the small size of the island, the observed climatic gradients are found to be quite important, a fact that supports the need for high-resolution simulations in order to properly model the climate regime of Cyprus. 
The current results and the magnitude of projected changes are expected: (i) to convince policy and decisions makers in considering more aggressive mitigation measures and (ii) to motivate stakeholders in designing and implementing updated strategies for climate change adaptation. Such groups of stakeholders might include water and energy management authorities and municipalities.

According to recent studies, there are strong indications that higher resolution, convection-permitting simulations can improve the representation of extreme precipitation events [13,46-48]. Nevertheless, these types of experiments are not yet widely applied for extended areas or long-range climate simulations due to the heavy computational cost involved.

Large multimodel and multiscenario ensembles are expected to add value and provide a more representative range of possible futures [7,49]. In this respect, downscaling of multiple global models and future pathways or scenarios are needed.

Author Contributions: Conceptualization, G.Z. and A.B.; methodology, G.Z. and A.B.; validation, G.Z., and C.C.; formal analysis, G.Z.; resources, A.B.; data curation, G.Z. and C.C.; writing-original draft preparation, G.Z.; writing-review and editing, A.B. and C.C.; supervision, A.B.; funding acquisition, A.B. All authors have read and agreed to the published version of the manuscript.

Funding: This research was supported by the ERMIS-Floods project that has received funding from the European Union's Interreg V-A Greece-Cyprus 2014-2020 Programme, under grant agreement no. 5603 and was co-funded by the Republic of Cyprus and the Hellenic Republic. It was also supported by the EMME-CARE project that has received funding from the European Union's Horizon 2020 Research and Innovation Programme, under grant agreement no. 856612, as well as matching co-funding by the Government of the Republic of Cyprus.

Conflicts of Interest: The authors declare no conflict of interest. The funders had no role in the design of the study; in the collection, analyses, or interpretation of data; in the writing of the manuscript, or in the decision to publish the results. This publication reflects only the authors' view. The European Community is not liable for any use that may be made for the information contained herein.

\section{References}

1. Giorgi, F. Climate change hot-spots. Geophys. Res. Lett. 2006, 33, L08707. [CrossRef]

2. Diffenbaugh, N.S.; Giorgi, F. Climate change hotspots in the CMIP5 global climate model ensemble. Clim. Chang. 2012, 114, 813-822. [CrossRef]

3. Giorgi, F.; Lionello, P. Climate change projections for the Mediterranean region. Glob. Planet. Chang. 2008, 63, 90-104. [CrossRef]

4. Lelieveld, J.; Hadjinicolaou, P.; Kostopoulou, E.; Chenoweth, J.; Maayar, M.; Giannakopoulos, C.; Hannides, C.; Lange, M.; Tanarhte, M.; Tyrlis, E.; et al. Climate change and impacts in the Eastern Mediterranean and the Middle East. Clim. Chang. 2012, 114, 667-687. [CrossRef]

5. Lelieveld, J.; Proestos, Y.; Hadjinicolaou, P.; Tanarhte, M.; Zittis, G. Strongly increasing heat extremes in the Middle East and North Africa (MENA) in the 21st century. Clim. Chang. 2016, 137, 245-260. [CrossRef]

6. Cramer, W.; Guiot, J.; Fader, M.; Gattuso, J.P.; Iglesias, A.; Lange, M.A.; Lionello, P.; Llasat, M.C.; Paz, S.; Peñuelas, J.; et al. Climate change and interconnected risks to sustainable development in the Mediterranean. Nat. Clim. Chang. 2018, 8, 972-980. [CrossRef]

7. Zittis, G.; Hadjinicolaou, P.; Klangidou, M.; Proestos, Y.; Lelieveld, Y. A multi-model, multi-scenario, and multi-domain analysis of regional climate projections for the Mediterranean. Reg. Environ. Chang. 2019, 19, 2621-2635. [CrossRef]

8. Kharin, V.V.; Zwiers, F.W.; Zhang, X.; Wehner, M. Changes in temperature and precipitation extremes in the CMIP5 ensemble. Clim. Chang. 2013, 119, 345-357. [CrossRef]

9. Paxian, A.; Hertig, E.; Seubert, S.; Vogt, G.; Jacobeit, J.; Paeth, H. Present-day and future Mediterranean precipitation extremes assessed by different statistical approaches. Clim. Dyn. 2014, 44, 845-860. [CrossRef]

10. Kitoh, A.; Endo, H. Changes in precipitation extremes projected by a 20-km mesh global atmospheric model. Weather Clim. Extrem. 2016, 11, 41-52. [CrossRef]

11. Tramblay, Y.; Somot, S. Future evolution of extreme precipitation in the Mediterranean. Clim. Chang. 2018, 151, 289-302. [CrossRef]

12. Lionello, P.; Scarascia, L. The relation of climate extremes with global warming in the Mediterranean region and its north versus south contrast. Reg. Environ. Chang. 2020, 20, 31. [CrossRef] 
13. Zittis, G.; Bruggeman, A.; Camera, C.; Hadjinicolaou, P.; Lelieveld, J. The added value of convection permitting simulations of extreme precipitation events over the eastern Mediterranean. Atmos. Res. 2017, 191, 20-33. [CrossRef]

14. Kotlarski, S.; Keuler, K.; Christensen, O.B.; Colette, A.; Déqué, M.; Gobiet, A.; Goergen, K.; Jacob, D.; Lüthi, D.; van Meijgaard, E.; et al. Regional climate modeling on European scales: A joint standard evaluation of the EURO-CORDEX RCM ensemble. Geosci. Model Dev. 2014, 7, 1297-1333. [CrossRef]

15. Torma, C.; Giorgi, F.; Coppola, E. Added value of regional climate modeling over areas characterized by complex terrain-precipitation over the Alps. J. Geophys. Res. 2015, 120, 3957-3972. [CrossRef]

16. Soares, P.M.M.; Cardoso, R.M. A simple method to assess the added value using high-resolution climate distributions: Application to the EURO-CORDEX daily precipitation. Int. J. Climatol. 2018, 38, 1484-1498. [CrossRef]

17. Prein, A.F.; Gobiet, A.; Truhetz, H.; Keuler, K.; Goergen, K.; Teichmann, C.; Maule, C.F.; van Meijgaard, E.; Déqué, M.; Nikulin, G.; et al. Precipitation in the EURO-CORDEX $0.11 \circ$ and $0.44 \circ$ simulations: High resolution, high benefits? Clim. Dyn. 2016, 46, 383-412. [CrossRef]

18. Peel, M.C.; Finlayson, B.; McMahon, T.A. Updated world map of the Köppen-Geiger climate classification. Hydrol. Earth Syst. Sci. 2007, 11, 1633-1644. [CrossRef]

19. Camera, C.; Bruggeman, A.; Hadjinicolaou, P.; Pashiardis, S.; Lange, M.A. Evaluation of interpolation techniques for the creation of gridded daily precipitation $\left(1 \times 1 \mathrm{~km}^{2}\right)$; Cyprus, 1980-2010. J. Geophys. Res. Atmos. 2014, 119, 693-712. [CrossRef]

20. Christofi, C.; Bruggeman, A.; Kuells, C.; Constantinou, C. Hydrochemical evolution of groundwater in gabbro of the Troodos Fractured Aquifer. A comprehensive approach. Appl. Geochem. 2020, 114, 104524. [CrossRef]

21. Zittis, G. Observed rainfall trends and precipitation uncertainty in the vicinity of the Mediterranean, Middle East and North Africa. Theor. Appl. Climatol. 2018, 134, 1207-1230. [CrossRef]

22. Hoerling, M.; Eischeid, J.; Perlwitz, J.; Quan, X.; Zhang, T.; Pegion, P. On the increased frequency of Mediterranean drought. J. Clim. 2012, 25, 2146-2161. [CrossRef]

23. Cook, B.I.; Anchukaitis, K.J.; Touchan, R.; Meko, D.M.; Cook, E.R. Spatiotemporal drought variability in the Mediterranean over the last 900 years. J. Geophys. Res. 2016, 121, 2060-2074. [CrossRef] [PubMed]

24. Giorgi, F.; Gutowski, W.J. Coordinated Experiments for Projections of Regional Climate Change. Curr. Clim. Chang. Rep. 2016, 2, 202-210. [CrossRef]

25. Jacob, D.; Petersen, J.; Eggert, B.; Alias, A. EURO-CORDEX: New high-resolution climate change projections for European impact research. Reg. Environ. Chang. 2014, 14, 563-578. [CrossRef]

26. Camera, C.; Bruggeman, A.; Hadjinicolaou, P.; Michaelides, S.; Lange, M.A. Evaluation of a spatial rainfall generator for generating high resolution precipitation projections over orographically complex terrain. Stoch. Environ. Res. Risk Assess. 2017, 31, 757-773. [CrossRef]

27. Giannakopoulos, C.; Hadjinicolaou, P.; Kostopoulou, E.; Varotsos, K.V.; Zerefos, C. Precipitation and temperature regime over Cyprus as a result of global climate change. Adv. Geosci. 2010, 23, 17-24. [CrossRef]

28. Hadjinicolaou, P.; Giannakopoulos, C.; Zerefos, C.; Lange, M.A. Mid-21st century climate and weather extremes in Cyprus as projected by six regional climate models. Reg. Environ. Chang. 2011, 11, 441-457. [CrossRef]

29. Giannakis, E.; Serghides, D.; Dimitriou, S.; Zittis, G. Land Transport $\mathrm{CO}_{2}$ emissions and Climate Change: Evidence from Cyprus. Int. J. Sustain. Energ. 2020. [CrossRef]

30. Skamarock, W.C.; Klemp, J.B.; Dudhia, J.; Gill, D.O.; Barker, D.M.; Duda, M.G.; Huang, X.-Y.; Wang, W.; Powers, J.G. A Description of the Advanced Research WRF Version 3; NCAR Technical Note, NCAR/TN-475+STR; National Center for Atmospheric Research: Boulder, CO, USA, 2008.

31. Fita, L.; Polcher, J.; Giannaros, T.M.; Lorenz, T.; Milovac, J.; Sofiadis, G.; Katragkou, E.; Bastin, S. CORDEX-WRF v1.3: Development of a module for the Weather Research and Forecasting (WRF) model to support the CORDEX community. Geosci. Model Dev. 2019, 12, 1029-1066. [CrossRef]

32. Iacono, M.J.; Delamere, J.S.; Mlawer, E.J.; Shephard, M.W.; Clough, S.A.; Collins, D. Radiative forcing by long-lived greenhouse gases: Calculations with the AER radiative transfer models. J. Geophys. Res. Atmos. 2008, 113, D13103. [CrossRef]

33. Janjic, Z.I. The step-mountain eta coordinate model: Further developments of the convection, viscous sublayer, and turbulence closure schemes. Mon. Weather Rev. 1994, 122, 927-945. [CrossRef] 
34. Tewari, M.; Chen, F.; Wang, W.; Dudhia, J.; LeMone, M.A.; Mitchell, K.; Ek, M.; Gayno, G.; Wegiel, J.; Cuenca, R.H. Implementation and verification of the unified NOAH land surface model in the WRF model. In Proceedings of the 20th Conference on Weather Analysis and Forecasting/16th Conference on Numerical Weather Prediction, Seattle, WA, USA, 10-12 January 2004; pp. 11-15.

35. Bruyère, C.L.; Done, J.M.; Holland, G.J.; Fredrick, S. Bias corrections of global models for regional climate simulations of high-impact weather. Clim. Dyn. 2013, 43, 1847-1856. [CrossRef]

36. Bruyère, C.L.; Monaghan, A.J.; Steinhoff, D.F.; Yates, D. Bias-Corrected CMIP5 CESM Data in WRF/MPAS Intermediate File Format; TN-515+STR; NCAR: Boulder, CO, USA, 2015; p. 27.

37. Zittis, G.; Bruggeman, A.; Hadjinicolaou, P.; Camera, C.; Lelieveld, J. Effects of meteorology nudging in regional hydroclimatic simulations of the Eastern Mediterranean. Atmosphere 2018, 9, 470. [CrossRef]

38. Riahi, K.; Rao, S.; Krey, V.; Cho, C.; Chirkov, V.; Fischer, G.; Kindermann, G.; Nakicenovic, N.; Rafaj, P. RCP 8.5-A scenario of comparatively high greenhouse gas emissions. Clim. Chang. 2011, 109, 33-57. [CrossRef]

39. Camera, C.; Bruggeman, A.; Hadjinicolaou, P.; Pashiardis, S.; Lange, M.A. High Resolution Gridded Datasets for Meteorological Variables: Cyprus, 1980-2010 and 2020-2050; AGWATER Scientific Report 5; The Cyprus Institute: Nicosia, Cyprus, 2013; p. 77.

40. Earth System Grid Federation Datanode, at the National Supercomputer Centre, Linköping. Available online: https://esg-dn1.nsc.liu.se/projects/esgf-liu/ (accessed on 30 March 2020).

41. Karl, T.R.; Nicholls, N.; Ghazi, A. CLIVAR/GCOS/WMO Workshop on Indices and Indicators for Climate Extremes-Workshop summary. Clim. Chang. 1999, 42, 3-7. [CrossRef]

42. Klein Tank, A.M.G.; Können, G.P. Trends in Indices of daily temperature and precipitation extremes in Europe, 1946-1999. J. Clim. 2003, 16, 3665-3680. [CrossRef]

43. Michaelides, S.; Nicolaides, K.; Karacostas, T. Statistical characteristics of the cold season depressions over the area of Cyprus. Meteorol. Cas. 2004, 7, 61-66.

44. Nicolaides, K.A.; Michalelides, S.C.; Karacostas, T. Synoptic and dynamic characteristics of selected deep depressions over Cyprus. Adv. Geosci. 2006, 7, 175-180. [CrossRef]

45. Pendergrass, A.G.; Coleman, D.B.; Deser, C.; Lehner, F.; Rosenbloom, N.; Simpson, I.R. Nonlinear Response of Extreme Precipitation to Warming in CESM1. Geophys. Res. Lett. 2019, 46, 10551-10560. [CrossRef]

46. Meredith, E.P.; Maraun, D.; Semenov, V.A.; Park, W. Evidence for added value of convection-permitting models for studying changes in extreme precipitation. J. Geophys. Res. 2015, 120, 12500-12513. [CrossRef]

47. Prein, A.F.; Langhans, W.; Fosser, G.; Ferrone, A.; Ban, N.; Goergen, K.; Keller, M.; Tölle, M.; Gutjahr, O.; Feser, F.; et al. A review on regional convection-permitting climate modeling: Demonstrations, prospects, and challenges. Rev. Geophys. 2015, 53, 323-361. [CrossRef] [PubMed]

48. Coppola, E.; Sobolowski, S.; Pichelli, E. A first-of-its-kind multi-model convection permitting ensemble for investigating convective phenomena over Europe and the Mediterranean. Clim. Dyn. 2018, 1-32. [CrossRef]

49. Legasa, M.N.; Manzanas, R.; Fernández, J.; García, S.H. Assessing multi-domain overlaps and grand ensemble generation in CORDEX regional projections. Geophys. Res. Lett. 2020, 47, e2019GL086799. [CrossRef]

(C) 2020 by the authors. Licensee MDPI, Basel, Switzerland. This article is an open access article distributed under the terms and conditions of the Creative Commons Attribution (CC BY) license (http://creativecommons.org/licenses/by/4.0/). 